\title{
Studies on the Endogenous Metabolism of Escherichia coli
}

\author{
By E. A. DAWES AND D. W. RIBBONS* \\ Department of Biochemistry, University of Hull
}

(Received 20 August 1964)

\begin{abstract}
1. The endogenous metabolism of Escherichia coli has been studied by examining changes in cellular composition and of the suspending fluid during starvation of washed suspensions of the organism, in water or in phosphate buffer, at $37^{\circ}$ under aerobic and anaerobic conditions. 2. When $E$. coli is grown in glucose-ammonium salts media the cells contain glycogen, which is utilized rapidly during subsequent starvation of the cells. 3. Ammonia is released by starved cells only after a lag period, which corresponds to the time taken for the cellular glycogen to be almost completely utilized. 4 . If cells are grown under conditions that permit incorporation of ${ }^{14} \mathrm{C}$ into protein but not into glycogen and are then starved, release of ${ }^{14} \mathrm{CO}_{2}$ commences immediately and continues at a linear rate throughout the period of glycogen utilization; it is concluded that the presence of glycogen in the cell prevents the net degradation of nitrogenous materials but does not suppress protein turnover. 5. RNA is degraded by the cells immediately they are starved, ribose is oxidized and ultraviolet-absorbing materials are released to the suspending medium. 6. There is no significant utilization of lipid during the starvation of glucose-grown $E$. coli. 7. There is no loss of viability during the initial $12 \mathrm{hr}$. period of starvation under either aerobic or anaerobic conditions, but thereafter the cells die more rapidly under conditions of anaerobiosis. 8. These results are discussed in relation to the known patterns of endogenous metabolism and survival of other bacteria.
\end{abstract}

The utilization of intracellular materials by bacteria during starvation, the so-called endogenous metabolism, is probably a phenomenon of universal occurrence (for reviews see Dawes \& Ribbons, 1962a, 1964). The energy derived from the oxidation of cellular constituents may be used to maintain the cell intact and to preserve viability until death eventually ensues. Experimental evidence in support of an energy of maintenance for Escherichia coli has been presented by McGrew \& Mallette (1962) and by Marr, Nilson \& Clark (1963), and current ideas on the energy of maintenance concept have been discussed by Dawes \& Ribbons (1964).

Although $\boldsymbol{E}$. coli has been extensively used in studies of bacterial metabolism, until recent years there has been little information on its metabolism when held in the absence of nutrients. Gronlund \& Campbell (1961) detected formation of ammonia during endogenous respiration of the organism and postulated that internal nitrogenous reserves served as substrates for endogenous metabolism, although the observed ratios of oxygen consumed to ammonia produced indicated that some non-

* Present address: Shell Research Ltd., Milstead Laboratory of Chemical Enzymology, Broad Oak Road, Sittingbourne, Kent. nitrogenous source, such as lipid or carbohydrate, was also utilized.

Dagley \& Dawes (1949) investigated factors influencing the carbohydrate content of $E$. coli, and the subsequent extensive researches of Holme \& Palmstierna $(1956 a, b)$ on the glycogen content of the organism suggested that this storage product may serve as an endogenous substrate, although this possibility was not tested.

Ribbons \& Dawes (1963) showed that the nature of the endogenous metabolism of $E$. coli depends on various environmental factors, and indicated a relationship to the nutritional status of the cells. We undertook the present work to attempt to resolve the role of carbohydrate and nitrogenous materials as endogenous substrates for $E$. coli and to study the survival pattern and changes in chemical composition that accompany starvation. Preliminary accounts have been presented to The Biochemical Society (Dawes \& Ribbons, 1962b,c).

\section{EXPERIMENTAL}

\section{Materials}

Organism. Escherichia coli N.C.T.C. 5928 was used throughout this work. The stock organism was maintained on nutrient-agar slants. 
Medium. This study was devoted exclusively to cells grown on defined medium of the following composition (g./l.): $\mathrm{KH}_{2} \mathrm{PO}_{4}, 5 \cdot 4 ; \mathrm{MgSO}_{4}, 7 \mathrm{H}_{2} \mathrm{O}, 0.4 ;\left(\mathrm{NH}_{4}\right)_{2} \mathrm{SO}_{4}, \mathrm{l} \cdot 2$; glucose, 8.0 ; the $\mathrm{pH}$ was adjusted to $7 \cdot 1$ with $5 \mathrm{~N}-\mathrm{NaOH}$. The glucose plus $\mathrm{MgSO}_{4}, 7 \mathrm{H}_{2} \mathrm{O}$ was sterilized separately and the solutions were mixed with aseptic precautions when cool. In medium of this composition the precise factor limiting growth is not known, but it is not glucose, nitrogen, magnesium, phosphorus or sulphur.

Growth of the organism. E. coli was maintained in liquid medium of the above composition and subcultured every 2 weeks by inoculation of sterile medium $(12.5 \mathrm{ml}$.) contained in conical flasks of $50 \mathrm{ml}$. capacity. Stationary-phase populations for inocula were obtained by overnight incubation $\left(16 \mathrm{hr}\right.$.) at $37^{\circ}$ in a Gallenkamp reciprocating water bath (60 oscillations/min.; stroke $4 \mathrm{~cm}$.). A freshly grown culture was always used to inoculate a second shaken culture $(12.5 \mathrm{ml}$.), which reached the end of the exponential growth phase in 6-8 hr. A portion ( $1 \mathrm{ml}$.) of this culture was used to inoculate fresh medium $(500 \mathrm{ml}$. or 11 .) contained in 11. boiling flasks that were either aerated with sterile air or left static, according to the experimental requirements. Growth was followed turbidimetrically and cells for experimental work were harvested just after the onset of the stationary phase. Larger batches of cells were obtained with 5 or 101. of medium contained in boiling flasks (101.), the former being fitted with coarse sinteredglass aeraters for aeration. Inocula for these large batches were $1 \%$ (50 or $100 \mathrm{ml}$. respectively) of a $15 \mathrm{hr}$. culture and the temperature of incubation was $37^{\circ}$. Bulk cultures were harvested with an air-turbine Sharples no. 1A laboratory super-centrifuge at $50000 \mathrm{rev} / \mathrm{min}$.; smaller volumes of culture were centrifuged at $15000 \mathrm{~g}$ for $3 \mathrm{~min}$. in either an MSE Angle 13 centrifuge or a Servall SS-1 centrifuge without refrigeration.

The cells were generally washed twice with distilled water before resuspension to a desired cell density in phosphate buffer $\left(0 \cdot 67 \mathrm{M}-\mathrm{KH}_{2} \mathrm{PO}_{4}\right.$ adjusted to $\mathrm{pH} 7 \cdot 1$ with $5 \mathrm{~N}-\mathrm{NaOH})$. Deviations from this standard procedure, e.g. the use of ice-cold washes and overnight storage of cells as a pellet at $4^{\circ}$, are indicated in the individual Tables and Figures. Some effects of overnight storage have been recorded (Ribbons \& Dawes, 1963).

Chemicals. Analytical-reagent-grade chemicals (Hopkin and Williams Ltd., Chadwell Heath, Essex; British Drug Houses Ltd., Poole, Dorset) were used wherever possible; other chemicals were of the best available purity from the same suppliers, and were recrystallized.

Radiochemicals. The ${ }^{14} \mathrm{C}$-labelled algal-protein hydrolysate and [U-14C]glucose were obtained from The Radiochemical Centre, Amersham, Bucks.

\section{Analytical methods}

Bacterial densities and growth. Bacterial densities were determined turbidimetrically either in a Hilger Spekker absorptiometer with Chance glass filters H508 and OB2 or a Unicam SP. 600 spectrophotometer at $570 \mathrm{~m} \mu$; extinctions were converted into bacterial densities from curves relating bacterial dry weight to extinction. Bacteria were washed and dried at $105^{\circ}$ for $18 \mathrm{hr}$. Bacterial growth was followed turbidimetrically by the method of Dagley, Dawes \& Morrison (1950).

Carbohydrate. Carbohydrate was determined by the anthrone method of Trevelyan \& Harrison (1952). Total cell carbohydrate hexose was measured by pipetting suitable aqueous suspensions of cells into the ice-cold anthrone reagent. The alkali-stable polyglucose (glycogen) of $E$. coli was extracted, washed and precipitated precisely as described by Palmstierna (1956). Purification of extracted glycogen was also carried out by the procedure of Cowgill \& Pardee (1957). Reducing sugar was determined by the method of Nelson (1944).

Ribose. Free and purine-bound ribose was estimated by the orcinol method (Mejbaum, 1939) on cell-free supernatants, cell suspensions or the alkali-soluble nucleotides.

Amino acids and ammonia. Amino acids were estimated by the method of Yemm \& Cocking (1955). Glycine and $\left(\mathrm{NH}_{4}\right)_{2} \mathrm{SO}_{4}$ were used as standards and values were corrected for the presence of ammonia, which was estimated independently by nesslerization (Paul, 1958). Ammonia was also determined by the more sensitive chloroindophenol method of Bolleter, Bushman \& Tidwell (1961).

Peptides. Peptides were estimated by the method described by Dawes \& Holms (1958a).

Free amino acid pools. Cell suspensions were immersed in boiling water for $10 \mathrm{~min}$. and then centrifuged to obtain the clear supernatants containing free amino acids.

Protein. Protein was estimated by the methods of Lowry, Rosebrough, Farr \& Randall (1951) and Stickland (1951), with bovine serum albumin, fraction V (Sigma Chemical

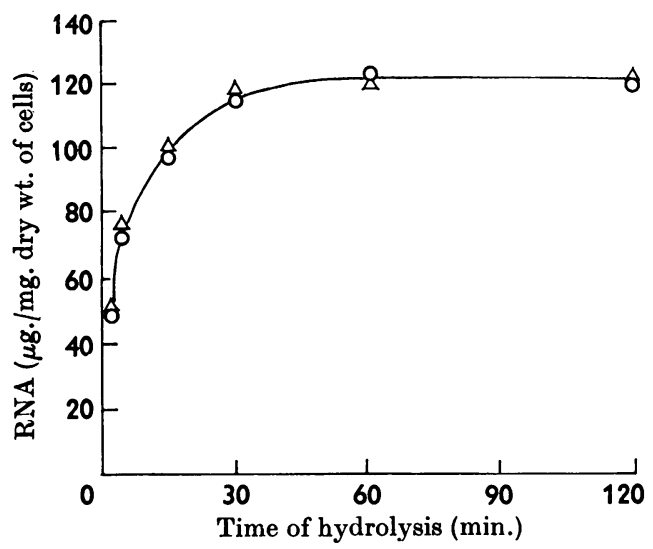

Fig. 1. Extraction and hydrolysis of RNA from $E$. coli by the procedure of Fleck \& Munro (1962). Portions (2 ml.) of a suspension of $E$. coli $(6 \mathrm{mg} . / \mathrm{ml}$.) were treated with $1 \mathrm{ml}$. of $2 \cdot 1 \mathrm{~N}$-perchloric acid at $0^{\circ}$ for $10 \mathrm{~min}$. The precipitates were washed twice with $0.7 \mathrm{~N}$-perchloric acid at $0^{\circ}$. The extracted residues were then digested at $37^{\circ}$ in $0.3 \mathrm{~N}-\mathrm{KOH}$ $(3 \mathrm{ml}$.) in a water bath for periods as indicated. At the end of each incubation the samples were neutralized and made $1 \mathrm{~N}$ with respect to perchloric acid, at $0^{\circ}$. The precipitate was washed twice with cold $0.5 \mathrm{~N}$-perchloric acid and the supernatants were made up to 25 or $50 \mathrm{ml}$. as desired in $0.5 \mathrm{~N}$-perchloric acid. The extinctions of the solutions were read at $260 \mathrm{~m} \mu$ and their ribose contents estimated. Results are calculated as described in the Experimental section for ribose $(\Delta)$ and $E_{260}(O)$. 
Co., St. Louis, Mo., U.S.A.), as standard. These methods gave identical results with cells; the biuret method was not tested with supernatants.

$R N A$. RNA was extracted from the bacteria as ribonucleotides by alkaline hydrolysis $(0 \cdot 3 \mathrm{~N}-\mathrm{KOH}$ for $60 \mathrm{~min}$. at $37^{\circ}$ ) of perchloric acid-washed cells. The procedure was that described by Fleck \& Munro (1962); essentially all the RNA was hydrolysed within $60 \mathrm{~min}$. at $37^{\circ}$ (Fig. 1). The alkali-soluble material and washings of the residue were made up to $50 \mathrm{ml}$. in $\mathrm{N}$-perchloric acid, and the ultravioletabsorption spectra and the ribose content of these solutions determined. The values obtained were related to RNA content by using the base composition of $E$. coli reported by Roberts, Abelson, Cowie, Bolton \& Britten (1957).

Spectra and ultraviolet measurements were carried out with either a Cary or a Beckman DB recording spectrophotometer.

Ethanol. Ethanol was determined on neutral steamvolatile distillates of suspending fluids by dichromate oxidation, followed by estimation of the residual dichromate with $\mathrm{KI}$ and $\mathrm{Na}_{2} \mathrm{~S}_{2} \mathrm{O}_{3}$ (Neish, 1952, 1957).

Steam-volatile acids. These were separated by steamdistillation in a Markham still after adjusting to $\mathrm{pH} 1$ by the addition of $\mathrm{H}_{2} \mathrm{SO}_{4}$. Six volumes of distillate were collected and titrated with $0.02 \mathrm{~N}-\mathrm{NaOH}$ in a stream of $\mathrm{CO}_{2}$-free air, with phenol red as indicator.

\section{Manometric methods}

The manometric methods used were as described by Ribbons \& Dawes (1963). Anaerobic-starvation experiments were sometimes performed without $\mathrm{KOH}$ in the centre well of the flasks; as both hydrogen and carbon dioxide are evolved under these conditions by cells that contain glycogen, the endogenous fermentation rate is expressed as a $Q_{\left(\mathrm{CO}_{2}+\mathrm{H}_{2}\right)}^{\mathrm{N}_{2}}$ value.

\section{Protein-turnover experiments}

To obtain cells that have their proteins uniformly labelled with ${ }^{14} \mathrm{C}$ but their glycogen unlabelled, medium of the following composition was prepared (g./l.): glucose, $8 \cdot 0 ; \mathrm{MgSO}_{4}, 7 \mathrm{H}_{2} \mathrm{O}, 0.4$; casein hydrolysate (Bacto casamino acids; Difco Laboratories, Detroit, Mich., U.S.A.), 0.01; $\mathrm{KH}_{2} \mathrm{PO}_{4}, 5 \cdot 4 ;\left(\mathrm{NH}_{4}\right)_{2} \mathrm{SO}_{4}, 0.8 ; \mathrm{pH}$ adjusted to $7 \cdot 1$ with $5 \mathrm{~N}-\mathrm{NaOH}$. The glucose plus $\mathrm{MgSO}_{4}, 7 \mathrm{H}_{2} \mathrm{O}$ was sterilized separately and added aseptically when cool. Sterile ${ }^{14} \mathrm{C}$-labelled algal-protein hydrolysate was then added $(10 \mu \mathrm{c}, 77 \mu \mathrm{g}$.). The medium was prepared in 11 . boiling flasks, filled to the neck to secure semi-anaerobic conditions, and each flask given a light inoculum $(0.1 \mathrm{ml}$.) of a stationary-phase glucose-ammonium salts culture. Nitrogen exhaustion limits growth in this medium, and after growth had ceased the cells were harvested, washed three times on the centrifuge, initially with $0.67 \mathrm{M}$-phosphate buffer, $\mathrm{pH} 7 \cdot 1$, finally with distilled water, and then used for starvation experiments. The resulting cell suspension (approx. $6 \mathrm{mg} . / \mathrm{ml}$.) was distributed in portions $(2.6 \mathrm{ml}$.) in a series of Warburg flasks that contained $0.2 \mathrm{ml}$. of $5 \mathrm{~N}-\mathrm{NaOH}$ in the centre well and $0.2 \mathrm{ml}$. of $2 \mathrm{~N}-\mathrm{H}_{2} \mathrm{SO}_{4}$ in the side bulb. After temperature equilibration, acid was tipped from the side arms of two flasks (zero-time samples) and these were then used for analysis. Oxygen consumption was followed with the remaining flasks and at suitable intervals further pairs of flasks were removed after acid had been tipped from the side bulbs.

Alkali and filter papers were transferred quantitatively from the centre wells to $10 \mathrm{ml}$. measuring cylinders and the solution was made up to a known volume with $\mathrm{CO}_{2}$-free water. Cell suspensions were transferred to sample bottles before subsequent analysis. The total carbohydrate content and radioactivity of the cells and the ammonia content of the suspending fluid were determined. The radioactivity of the respiratory $\mathrm{CO}_{2}$ trapped in the alkali was measured by precipitation of replicate portions as $\mathrm{BaCO}_{3}$, by using the methods described by Sakami (1955). The radioactivity of the cells was determined by spreading portions ( 0.1 and $0.2 \mathrm{ml}$.) of suitably diluted suspensions on stainless-steel planchets having an effective raised area of $1 \cdot 5 \mathrm{~cm}^{2}$. (Dawes \& Holms, 1958b).

To confirm that the glycogen of cells grown under these conditions was not significantly labelled, glycogen was isolated from the cells, purified by the technique described by Cowgill \& Pardee (1957) and its radioactivity determined. Less than $1 \%$ of the total radioactivity of the cells was present in the glycogen.

Isotopic counting procedures. All estimations were made at or corrected to infinite thinness by using an end-window Geiger-Müller tube and an Ekco automatic scaler type N530G. Counts were collected for a period sufficient to ensure that the counting error was less than $\pm 2 \%$. Corrections were applied for background and coincidence.

\section{Cell fractionation}

To ascertain the fate of the lipid content of $E$. coli during starvation, cells were uniformly labelled by two subcultures and by growth in $\left[\mathrm{U}-{ }^{14} \mathrm{C}\right]$ glucose medium of the same composition [standard glucose-ammonium salts medium containing [U-14C]glucose $(50 \mu \mathrm{c}, 8 \cdot 0 \mathrm{~g}$. of glucose $/ \mathrm{l})$ ] and then, after being harvested and washed, subjected to the fractionation procedures described by Roberts et al. (1957). Usually about $10 \mathrm{mg}$. wet wt. of cells was taken for analysis. Variation of the lipid extraction solvents was tried in different experiments (Table 6).

\section{Starvation procedure}

Cells were starved either by aerating with water-saturated sterile air or by shaking washed suspensions of the organism at $37^{\circ}$ as described by Ribbons \& Dawes (1963). In some experiments, e.g. those designed to measure possible protein turnover, the starvation was carried out in Warburg flasks.

\section{Viability estimations}

To determine the survival characteristics of $E$. coli under the conditions of starvation used, a washed suspension was prepared, with precautions to prevent contamination, from cells freshly harvested from the standard glucose-ammonium salts medium. Portions $(10 \mathrm{ml}$.) of the suspension were distributed in a series of sterile $50 \mathrm{ml}$. conical flasks. For anaerobic-starvation experiments the flasks were flushed with nitrogen and sealed, whereas for aerobic experiments the flasks were sealed retaining an atmosphere of air. The flasks were incubated at $37^{\circ}$ on Gallenkamp reciprocating water baths (shaking rate 60 oscillations/min.; stroke 
$4 \mathrm{~cm}$.) and at appropriate times pairs of flasks were removed. Samples $(1 \mathrm{ml}$.) were removed with aseptic precautions and subjected to serial dilution with $1 \mathrm{ml}$. transfers to $100 \mathrm{ml}$. volumetric flasks, containing sterile phosphate buffer $\left(0.67 \mathrm{M}-\mathrm{KH}_{2} \mathrm{PO}_{4}\right.$ adjusted to $\mathrm{pH} 7 \cdot 1$ with $\left.5 \mathrm{~N}-\mathrm{NaOH}\right)$, to secure a final population of approx. $10^{2}$ cells $/ \mathrm{ml}$. Portions ( $1 \mathrm{ml}$.) of the final dilution were added to replicate test tubes containing $9 \mathrm{ml}$. of sterile nutrient-agar, which were held at $45^{\circ}$ to keep the agar molten, mixed thoroughly and poured into sterile Petri dishes. Colonies were counted after incubation for 24 and $36 \mathrm{hr}$.

The remainder of the cells from each incubation flask was used for chemical analyses.

\section{RESULTS}

Exponential-phase cells. Aeration of washed suspensions of aerobically grown $E$. coli that have been harvested during the exponential phase of growth causes a rapid decrease in the carbohydrate content and $Q_{0}$, (endogenous) value of the cells (Fig. 2). After approx. $60 \mathrm{~min}$. there is no further

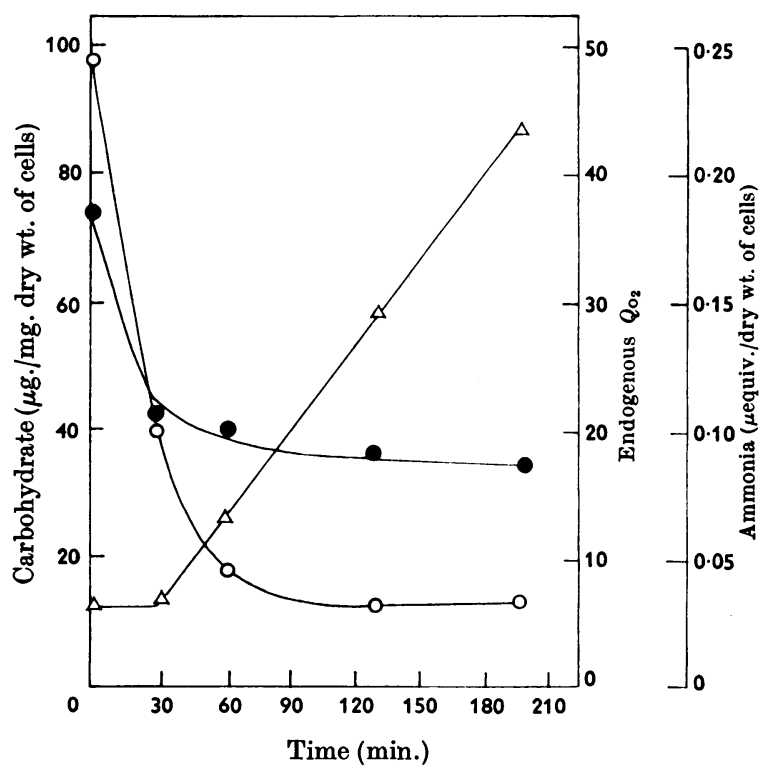

Fig. 2. Carbohydrate content, endogenous respiration rate and ammonia release during starvation of a washed suspension of aerobically grown $E$. coli harvested during exponential growth. A cell suspension (100 ml.; 13.6 mg./ ml.) in $0.67 \mathrm{M}$-phosphate buffer, $\mathrm{pH} 6.8$, was aerated with water-saturated air at $37^{\circ}$, and at intervals samples $(10 \mathrm{ml}$.) were withdrawn into $25 \mathrm{ml}$. of ice-cold water and centrifuged. At the same time samples $(5 \mathrm{ml}$.) were taken and used immediately for Warburg determinations. The cell pellets were resuspended in ice-cold water and samples taken for cell density measurements and chemical analysis. $\bullet$, Total cellular carbohydrate; $\bigcirc, Q_{\mathrm{O}_{2}}$ (endogenous); $\triangle$, ammonia released from cells. utilization of carbohydrate and the $Q_{0_{2}}$ levels out at a small but finite value, suggesting that material other than carbohydrate is now being oxidized. Ammonia is released from the cells, but only after a short lag period, which corresponds to the time during which carbohydrate is being metabolized. Although this lag period is characterized by only two experimental points in Fig. 2, it has been thoroughly documented elsewhere (Tables 1, 2 and 4, and Ribbons \& Dawes, 1963).

The free amino acid pool of the cells was examined to determine whether it was the source of the ammonia (Fig. 3). There is little ammonia in the hot-water-extractable pool and it does not increase during starvation. The concentration of the ninhydrin-positive substances is undiminished and, in fact, increases slightly, apparently to attain a threshold value, after which amino acids are released into the suspending fluid, together with the ammonia. Individual amino acids were not determined. Similar results were obtained with exponential-phase cells that had been grown without aeration.

Extraction and determination of cellular glycogen revealed that this was the rapidly utilized carbohydrate, and that when it was exhausted the

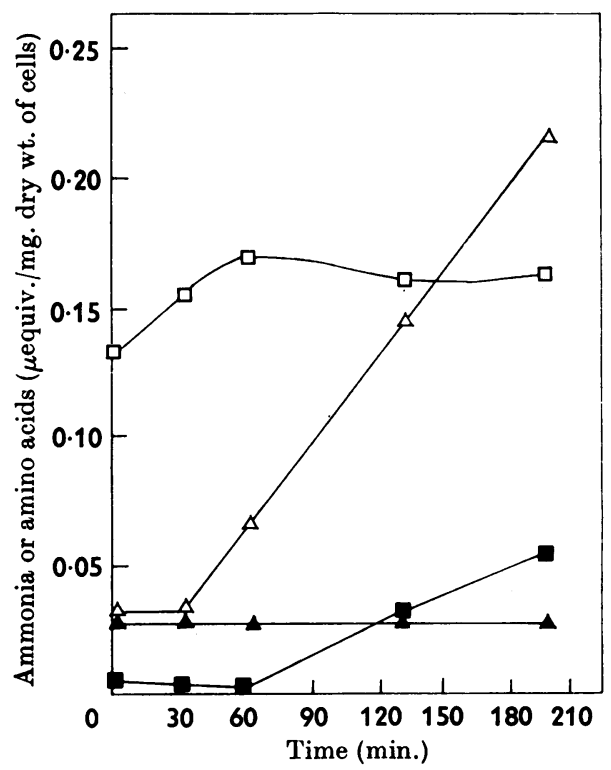

Fig. 3. Ammonia and amino acid release during starvation of a washed suspension of aerobically grown $E$. coli harvested during exponential growth. Details were as given for Fig. 2. $\Delta$, Ammonia in hot-water-extractable pool; $\Delta$, ammonia released from cells; $\square$, total amino acids in pool; $\square$, total amino acids released from cells. 
carbohydrate content of the cells remained constant, usually at about $3 \%$ of the dry weight.

Stationary-phase cells. One of the factors that determines the nature of the endogenous metabolism is the phase of growth from which the cells are harvested (Ribbons \& Dawes, 1963). The observed differences between exponential-phase and stationary-phase cells are quantitative ones. Stationaryphase cells respire endogenously at higher rates and contain large reserves of glycogen, which is the initial substrate oxidized. Starvation experiments with stationary-phase cells have generally been more extensive in both the period of starvation and the analyses of the cells and their products. Table 1 records the changes that occur during the aerobic starvation of anaerobically grown cells. The fall in dry weight, $Q_{\mathrm{O}_{2}}$ and $Q_{\left(\mathrm{CO}_{2}+\mathrm{H}_{2}\right)}^{\mathrm{N}_{2}}$ values is paralleled by the loss of carbohydrate, which occurs mainly from the glycogen fraction of the cells. The glycogen is apparently oxidized since it does not appear as carbohydrate in the suspending fluid; the concentration of the nonreducing extracellular carbohydrate in the supernatant remained unchanged. Release of ammonia and amino acids occurs only after at least $90 \%$ of the glycogen has been utilized. The lower respiratory quotient observed at this stage could not be confirmed in other experiments.

Anaerobic starvation. Washed suspensions of cells grown anaerobically under an atmosphere of nitrogen were starved under nitrogen at $37^{\circ}$ in a series of $50 \mathrm{ml}$. conical flasks. The cells and suspending fluid were analysed (Table 2).

The glycogen fraction is again metabolized very rapidly; neutral and acidic volatile products are formed and released to the suspending fluid. The yield of these fermentation products (approx. $7 \cdot 5 \mu$ equiv. of ethanol $/ \mathrm{ml}$. and approx. $7 \cdot 1 \mu$ equiv. of steam-volatile acid $/ \mathrm{ml}$. from $7 \cdot 7 \mu$ equiv. of hexose residues in glycogen) indicates that the endogenous fermentation involves only a thioclastic cleavage of pyruvate. (These cells have an active formate-hydrogenlyase system and acetate is the principal steam-volatile acid.) The small amount of extracellular carbohydrate again undergoes no change.

The endogenous $Q_{\mathrm{O}_{2}}$ values of the anaerobically starved cells does not fall at an appreciable rate (cf. aerobic starvation in Table 1), which supports our previous conclusion (Ribbons \& Dawes, 1963) that this 'residual' oxygen consumption is due to the unfermented glycogen fraction. In this experiment the cells had been washed free of the products of endogenous fermentation before oxygen consumption was measured.

Substrates of endogenous metabolism. The experiments so far described do not indicate the source of the ammonia. However, cell materials other than
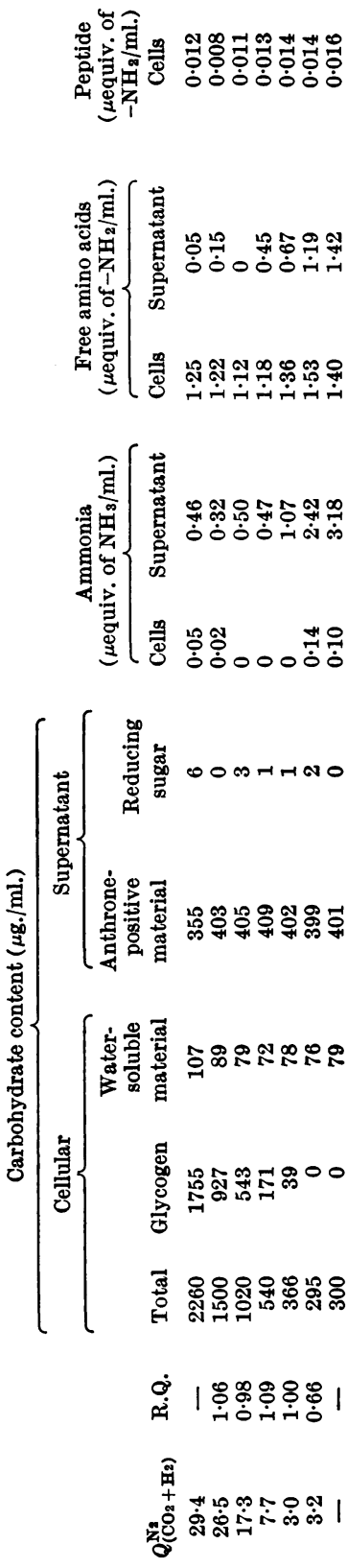

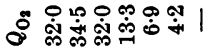

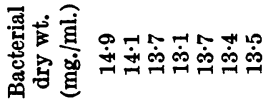

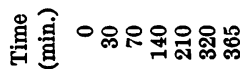




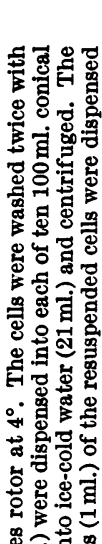

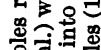

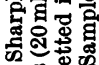

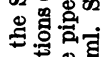

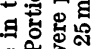

噪我家

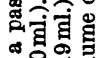

๙유월

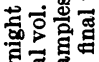

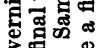

ชิ

분형

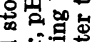

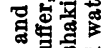

घ․워

되 ई

ठิ

.స్స ई

है

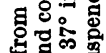

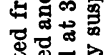

胥

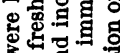

政里

完实

夏密

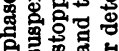

窟要

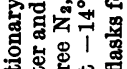

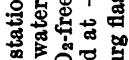

ง

잉

골

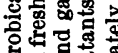

边。

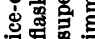
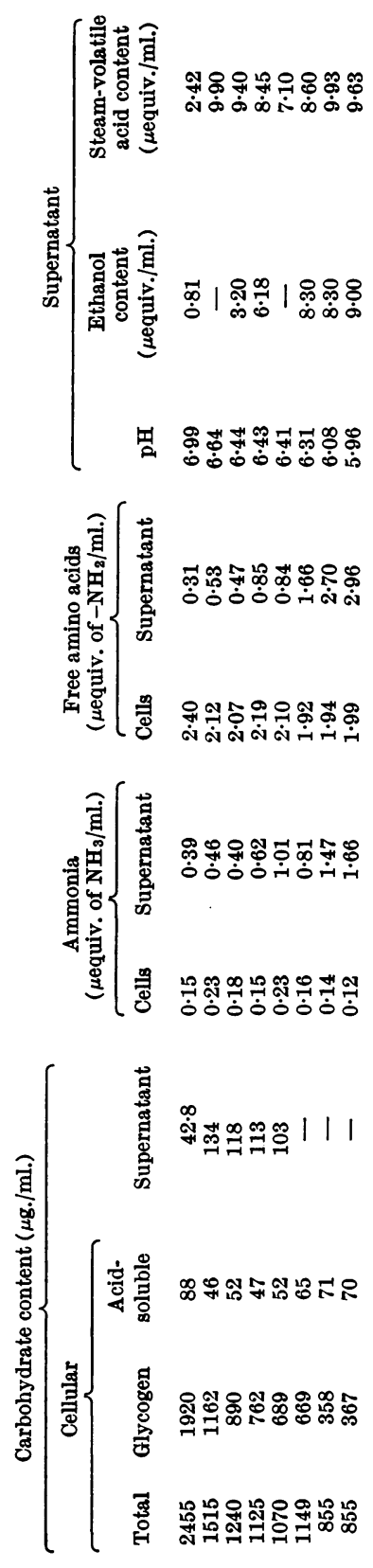

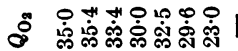

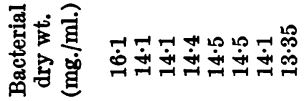

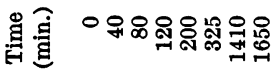

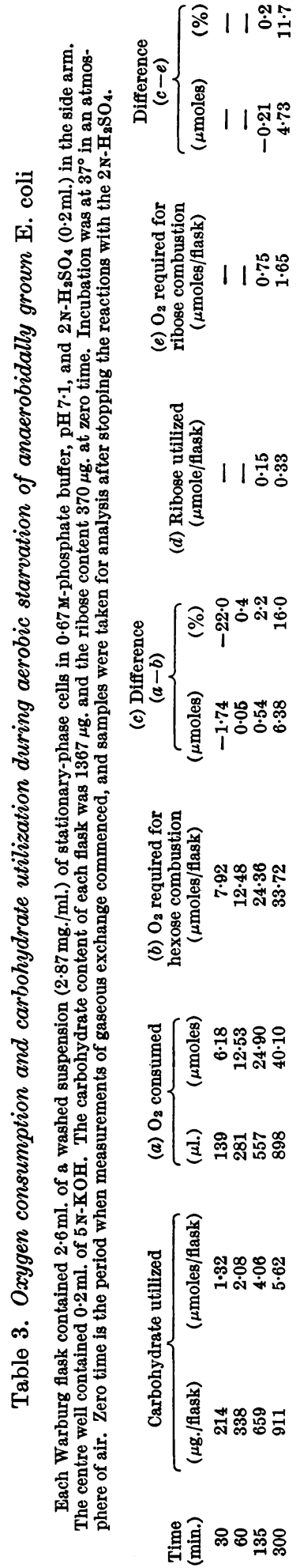




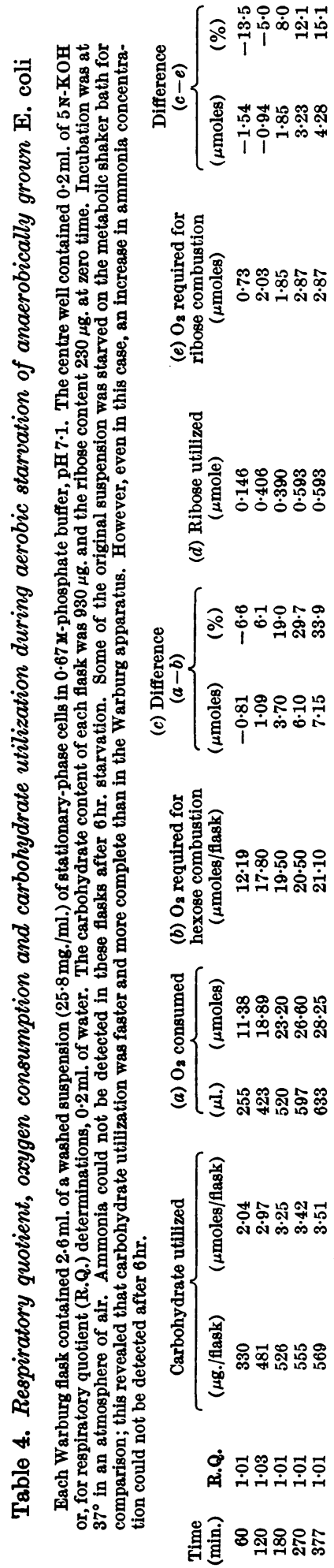

glycogen are degraded and oxidized, since amino acids and ultraviolet-absorbing materials are released from the cells and, after the initial $60 \mathrm{~min}$. of starvation, the consumption of oxygen is in excess of that required for the complete combustion of glycogen alone. Tables 3 and 4 record the total oxygen consumption during starvation, and the extent to which it is in excess of the requirement for complete oxidation of glycogen. Some of this excess can be accounted for by the oxidation of ribose (RNA, nucleotide, nucleoside and free). The other products of RNA degradation were not identified, although ultraviolet-absorbing materials are released into the suspending buffer (Fig. 4), and this occurs with cells starved under both aerobic and anaerobic conditions.

Experiments were undertaken to demonstrate the endogenous utilization of RNA with the results shown in Table 5. Ribose is lost from the cells immediately they are starved. Further, after its release from the RNA, ribose is either oxidized or fermented, according to the conditions of aerobiosis.

We could not demonstrate any significant utilization of fat reserves during starvation of glucose-grown $E$. coli. Lipid utilization had seemed unlikely in view of the report of Dagley \& Johnson (1953) that large amounts of fat are deposited during growth on acetate as the sole carbon and energy source but not when glucose serves in this

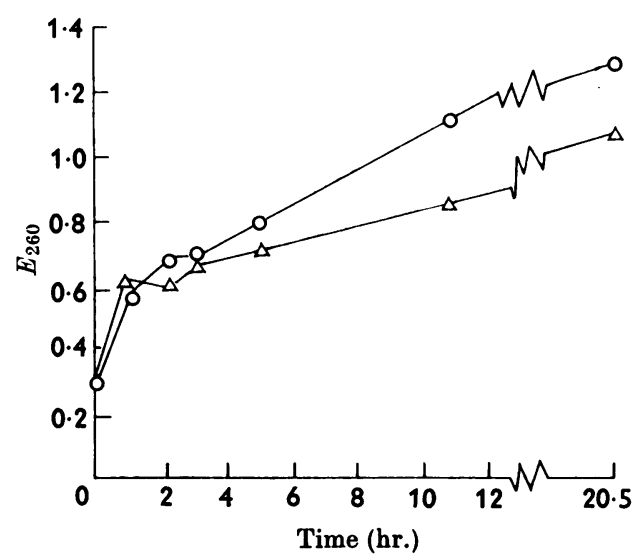

Fig. 4. Release of ultraviolet-absorbing material during aerobic and anaerobic starvation of $E$. coli. A washed suspension $(9.5 \mathrm{mg} . / \mathrm{ml}$.) of anaerobically grown stationaryphase cells in 0.67 M-phosphate buffer, $\mathrm{pH} 7 \cdot 1$, was dispensed into $50 \mathrm{ml}$. conical flasks and sealed under air or $\mathrm{N}_{2}$. Samples taken were diluted with an equal volume of ice-cold distilled water and the cells removed by centrifugation. The supernatants were diluted tenfold for determination of their $E_{260}$ values. $O$ Aerobic; $\Delta$, anaerobic. 
Table 5. Endogenous utilization and fate of $R N A$

Washed suspensions $(9.5 \mathrm{mg} . / \mathrm{ml}$. in $0.67 \mathrm{M}$-potassium-sodium phosphate buffer, $\mathrm{pH} 7 \cdot 1)$ of anaerobically grown stationary-phase cells were starved at $37^{\circ}$ by shaking in air or under $\mathrm{N}_{2}$. Samples (5 ml.) were taken as indicated, centrifuged and resuspended to $5 \mathrm{ml}$. with water. They were diluted appropriately for analysis of ribose (total) expressed as $\mu \mathrm{g}$. of orcinol-positive material/ml., and this was converted into RNA (column 4), whereas column 5 records $\mu \mathrm{g}$. of RNA/ml. as determined by the Fleck \& Munro (1962) procedure. Supernatants were analysed for ribose and ultraviolet-absorbing materials.

\begin{tabular}{|c|c|c|c|c|c|c|}
\hline \multirow[b]{2}{*}{$\begin{array}{l}\text { Expt. no. } \\
1\end{array}$} & \multirow[b]{2}{*}{$\begin{array}{l}\text { Time } \\
\text { (hr.) }\end{array}$} & \multicolumn{2}{|c|}{ Ribose (total) content of cells } & \multirow[b]{2}{*}{$\begin{array}{l}\text { RNA content } \\
\text { of cells } \\
(\mu \mathrm{g} \cdot / \mathrm{ml} .)\end{array}$} & \multirow{2}{*}{$\begin{array}{l}\text { Ribose in } \\
\text { supernatant } \\
\text { fluids } \\
(\mu \mathrm{g} . / \mathrm{ml} .)\end{array}$} & \multirow[b]{2}{*}{$\begin{array}{c}\text { Release of } E_{260} \\
\text { materials } \\
\left(\mathrm{E}_{260} / \mathrm{ml} .\right)^{*}\end{array}$} \\
\hline & & $\begin{array}{l}\text { As ribose } \\
(\mu \mathrm{g} . / \mathrm{ml} .)\end{array}$ & $\begin{array}{r}\text { As RNA } \\
(\mu \mathrm{g} . / \mathrm{ml} .)\end{array}$ & & & \\
\hline \multirow[t]{6}{*}{ (Air) } & 0 & 283 & 1060 & 800 & $15 \cdot 0$ & - \\
\hline & 3 & 218 & 825 & - & $18 \cdot 5$ & 0.45 \\
\hline & 6 & 215 & 810 & 650 & $16 \cdot 0$ & 0.52 \\
\hline & 10.5 & 219 & 820 & 720 & 13.9 & $0.6 \mathrm{~J}$ \\
\hline & 19.5 & 204 & 765 & 625 & $11 \cdot 3$ & 0.83 \\
\hline & 27 & 162 & 610 & 465 & $7 \cdot 3$ & $1 \cdot 31$ \\
\hline & & & & & & \\
\hline \multirow{6}{*}{ (Nitrogen) } & 0 & 290 & 1080 & 800 & $15 \cdot 1$ & - \\
\hline & 3 & 243 & 915 & 645 & $20 \cdot 0$ & 0.41 \\
\hline & 6 & 226 & 845 & 630 & $16 \cdot 5$ & 0.45 \\
\hline & 10.5 & 217 & 805 & 655 & $13 \cdot 0$ & 0.49 \\
\hline & 19.5 & 175 & 660 & 500 & $10 \cdot 0$ & 0.73 \\
\hline & 27 & 133 & 495 & 375 & $9 \cdot 2$ & 0.99 \\
\hline
\end{tabular}

* Readings for tenfold dilution of supernatants.

Table 6. Stability of the lipid fractions of E. coli during starvation under aerobic conditions

Cells grown anaerobically in a medium containing [U-14C]glucose (see the Experimental section) were harvested and washed three times with ice-cold distilled water, and a suspension $(4 \cdot 15 \mathrm{mg} . / \mathrm{ml}$.) in $0.67 \mathrm{M}$-phosphate buffer, pH 7.1, was starved at $37^{\circ}$ by shaking in air. Samples were fractionated by the procedures of Roberts et al. (1957) after various periods of starvation. Results of Expt. 1 are expressed as total counts $/ \mathrm{min} . / \mathrm{ml}$. of the starving suspension. Expts. 2 and 3 record different fractionations of the same starving suspension and are expressed as a percentage of the total counts $/ \mathrm{min} . / \mathrm{ml}$. of the cell suspension at zero time; the recorded counts at zero time were 165200 counts $/ \mathrm{min} . / \mathrm{ml}$. of cell suspension. The cell density at zero time was $6.5 \mathrm{mg} . / \mathrm{ml}$.

Total radioactivity of starving cell suspension (counts $/ \mathrm{min} . / \mathrm{ml}$.)

\begin{tabular}{|c|c|c|c|c|c|}
\hline & Starvation period $(\min .) \ldots$ & \multicolumn{2}{|c|}{$\mathbf{0}$} & \multirow{2}{*}{$\begin{array}{r}140 \\
44800 \\
2120 \\
18000 \\
6160\end{array}$} & \multirow{2}{*}{$\begin{array}{r}290 \\
43200 \\
2200 \\
16960 \\
5840\end{array}$} \\
\hline $\begin{array}{l}\text { Expt. no. } \\
1\end{array}$ & $\begin{array}{l}\text { Intact cells } \\
\text { Cold-trichloroacetic acid fraction } \\
\mathbf{7 5 \%} \text { Ethanol fraction } \\
\text { Hot-trichloroacetic acid fraction }\end{array}$ & $\begin{array}{r}53600 \\
2120 \\
17760 \\
9520\end{array}$ & $\begin{array}{r}53600 \\
2000 \\
18200 \\
9240\end{array}$ & & \\
\hline & & \multicolumn{4}{|c|}{ Percentage of total radioactivity in cell fractions } \\
\hline & Starvation period (min.)... & 0 & 120 & 340 & 1350 \\
\hline & $\begin{array}{l}75 \% \text { Ethanol fraction } \\
\text { Ethanol-other fraction } \\
\text { Hot-trichloroacetic acid fraction }\end{array}$ & $\begin{array}{r}20 \cdot 7 \\
1 \cdot 9 \\
25 \cdot 8\end{array}$ & $\begin{array}{r}21 \cdot 5 \\
1 \cdot 7 \\
24 \cdot 5\end{array}$ & $\begin{array}{r}19 \cdot 5 \\
2 \cdot 4 \\
23 \cdot 8\end{array}$ & $\begin{array}{r}19 \cdot 9 \\
1 \cdot 6 \\
18 \cdot 9\end{array}$ \\
\hline & $\begin{array}{l}\text { Cold-trichloroacetic acid fraction } \\
\text { Chloroform-methanol fraction } \\
\text { 75\% Ethanol fraction } \\
\text { Hot-trichloroacetic acid fraction } \\
\text { Residue }\end{array}$ & $\begin{array}{r}4 \cdot 5 \\
39 \cdot 9 \\
2 \cdot 0 \\
15 \cdot 4 \\
31 \cdot 4\end{array}$ & & $\begin{array}{r}4 \cdot 7 \\
39 \cdot 9 \\
11 \cdot 7 \\
25 \cdot 3\end{array}$ & $\begin{array}{r}3 \cdot 8 \\
34 \cdot 8 \\
\overline{9} \cdot 7 \\
27 \cdot 7\end{array}$ \\
\hline
\end{tabular}


capacity. Our experiments with cells uniformly labelled by growth on [U-14C]glucose as the sole source of carbon and of energy are reported in Table 6. The relative constancy of the radioactivity in the fractions extracted by the different lipid solvents employed illustrates the general stability of the lipid fraction of these cells during starvation.

Protein turnover and degradation. The results shown in Figs. 2 and 3 and Tables 1 and 2, as well as those obtained previously with cells grown in complex media (Ribbons \& Dawes, 1963), indicate that net degradation of protein does not occur until virtually all of the glycogen in the cells has been utilized. Cells grown on tryptone, which do not contain glycogen, degrade nitrogenous materials with release of ammonia immediately they are starved (Ribbons \& Dawes, 1963). The question posed is whether the presence of glycogen in the cells completely suppresses the metabolism of protein or whether turnover occurs during the period of glycogen utilization. To investigate this problem cells were grown anaerobically in an ammonium salt medium containing an excess of glucose as the sole carbon and energy source, with ${ }^{14} \mathrm{C}$-labelled protein hydrolysate and carrier amino acids added; nitrogen exhaustion limited growth in this medium (see the Experimental section).

Under these conditions it was found, as expected, that the cells contained a substantial amount of glycogen that was essentially unlabelled, whereas the proteins of the cell were heavily labelled. After

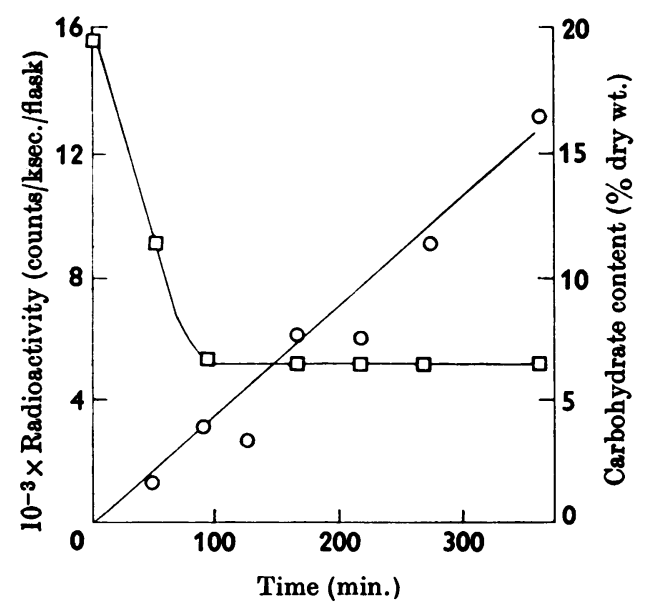

Fig. 5. Release, during starvation at $37^{\circ}$, of ${ }^{14} \mathrm{CO}_{2}$ from ${ }^{14} \mathrm{C}$-labelled protein of $E$. coli containing unlabelled glycogen. Details are given in the Experimental section. Each Warburg flask contained $17.9 \mathrm{mg}$. dry wt. of cells (total radioactivity 468000 counts/ksec.). $\square$, Total carbohydrate content of cells; $\mathrm{O},{ }^{14} \mathrm{CO}_{2}$ released. being harvested and washed, cells were starved in Warburg flasks as described in the Experimental section. Radioactivity appeared in the respiratory carbon dioxide at a linear rate immediately the cells were starved and throughout the period that glycogen was present in the cells (Fig. 5). It is concluded that glycogen does not suppress the turnover of protein during starvation.

It was observed throughout that when starvation experiments were conducted in Warburg flasks the rate of glycogen utilization was generally rather less than that in corresponding experiments with conical flasks in a water-bath shaker.

Survival of E. coli during starvation. The survival pattern of cells starved under the conditions used in the present work was investigated (Fig. 6). No significant death of cells occurs during the initial $12 \mathrm{hr}$. period under either aerobic or anaerobic conditions; but thereafter the cells die rather more rapidly under anaerobiosis, e.g. at $24 \mathrm{hr}$. there were 76 and $58 \%$ survivors under aerobic and anaerobic

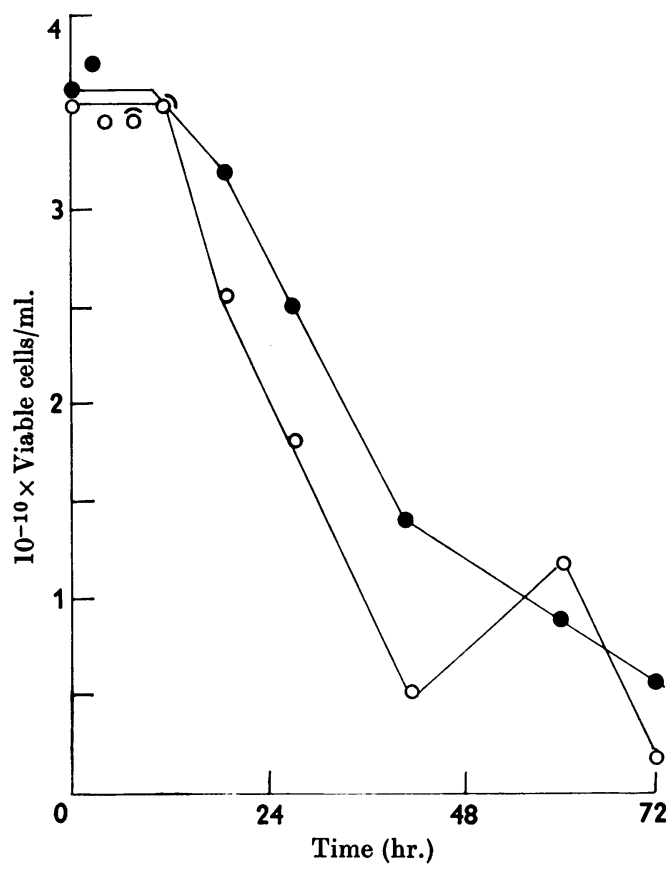

Fig. 6. Survival of $E$. coli starved under aerobic and anaerobic conditions at $37^{\circ}$. The cells were grown anaerobically and harvested 1-2 hr. after cessation of growth; the initial dry wt. of starving suspension was $9.5 \mathrm{mg} . / \mathrm{ml}$. Details are given in the Experimental section. Aerobic starvation: total cell counts at 0,27 and $72 \mathrm{hr}$. were $3.8 \times 10^{10}, 3.77 \times 10^{10}$ and $3.68 \times 10^{10}$ cells $/ \mathrm{ml}$. respectively. O, Anaerobic starvation: total cell counts at 0, 27 and $72 \mathrm{hr}$. were $3.78 \times 10^{10}, 3.59 \times 10^{10}$ and $3.83 \times 10^{10}$ cells/ ml. respectively. 
conditions respectively. Some other parameters of these experiments are shown in Table 7. These cells, although harvested from anaerobic cultures in the stationary phase, actually contained much less carbohydrate $(\mathbf{7 \cdot 3 5} \%)$ than was expected. The lower $\mathrm{pH}$ values of the supernatants from the anaerobic flasks may account for the differences in viability that are observed. The protein content of the cells was also measured, but no clear-cut demonstration of protein degradation in the aerobic series was possible, even though more protein, as revealed by the method of determination (Lowry et al. 1951) used, was released from the cells under aerobic conditions. Certainly some protein is degraded under anaerobic conditions. There is a fall in turbidity of the cell suspensions during starvation, a phenomenon that we previously correlated with the decrease in dry weight primarily associated with the loss of glycogen from the cells (Ribbons \& Dawes, 1963).

\section{DISCUSSION}

The existence of an endogenous metabolism in micro-organisms need not necessarily imply the existence of specialized reserves of either carbon or energy within the cell and, in the absence of nutrients, general cellular materials may be degraded. For example, Pseudomonas aeruginosa, an organism that when grown on glucose-ammonium salts media does not possess reserves of either carbohydrate or lipid, degrades RNA and protein when it is deprived of nutrients (Campbell, Gronlund \& Duncan, 1963; Gronlund \& Campbell, 1961, 1963). In organisms that do possess reserves, e.g. of carbohydrate, lipid (including poly- $\beta$ hydroxybutyrate) and possibly polyphosphate, the problem is raised of the relative importance of the reserves and of the cellular protein and RNA to endogenous metabolism. Does the possession of a reserve material exert a sparing action on the degradation of such 'basal' cell constituents as protein and RNA?

We have previously shown that $E$. coli grown on a glucose-ammonium salts medium always contains glycogen, the precise amount being a function both of the phase of growth from which the cells are harvested and of the conditions of aerobiosis employed (Ribbons \& Dawes, 1963). On subsequent starvation this glycogen is rapidly metabolized and, under the conditions employed in our experiments, is usually completely utilized in approx. $60 \mathrm{~min}$. and the oxygen consumed corresponds closely to that required for the complete oxidation of the glycogen. During the period of glycogen utilization the cells contain little ammonia and none is released from the cells; simultaneously with the disappearance of the glycogen ammonia release commences. 
Clearly glycogen is a preferentially utilized reserve and its possession by the cells prevents the net degradation of nitrogenous materials. The experiment with cells containing labelled protein reveals, however, that the mechanism is not one of complete suppression of protein metabolism since turnover is occurring, even during the period when the cells contain glycogen. The glycogen apparently serves as a source of both energy and of carbon to permit reincorporation of the ammonia released by protein breakdown. This situation may be compared with that observed by Duncan \& Campbell (1962) with $P$. aeruginosa, which releases ammonia immediately it is starved. The ammonia is reincorporated, however, if exogenous glucose is added to the cell suspension, and thus the endogenous glycogen of $E$. coli appears to fulfil a role similar to that of exogenous glucose in $P$. aeruginosa. The provision of an exogenous source of glucose for washed suspensions of $E$. coli further increases the lag period during which ammonia is not released (Ribbons \& Dawes, 1963). Tryptone-grown cells of $E$. coli, which are always devoid of glycogen, release ammonia immediately they are starved (Ribbons \& Dawes, 1963), thus emphasizing the role of glycogen in preventing the net degradation of nitrogenous materials under conditions of complete starvation. Holme \& Palmstierna (1956b) had previously demonstrated that glycogen could serve as a source of carbon for the synthesis of nitrogenous materials when $E$. coli was incubated with a nitrogen source in the absence of a carbon source.

The rate of release of ${ }^{14} \mathrm{CO}_{2}$ from labelled cellular protein during the utilization of endogenous glycogen corresponded to approx. $0.6 \%$ of the initial cellular radioactivity $/ \mathrm{hr}$. This is considerably less than the 4-5\% rate of protein turnover reported by Mandelstam (1958) and Mandelstam \& Halvorson (1960) for $E$. coli mutants starved of one essential amino acid in an otherwise adequate medium, or in the presence of an exogenous carbon and energy source. The difference may reflect a greater capacity for turnover in a medium that provides everything save a single nutrient, or furnishes an excess of a carbon and energy source, as opposed to starvation in a simple salt solution.

Cellular lipid was not significantly utilized by glucose-grown cells, but RNA degradation, as measured by ribose utilization, commenced immediately the organism was starved. It is known that the nucleic acids of exponentially growing $\boldsymbol{E}$. coli are stable, whereas in non-growing cells, irrespective of the factor causing cessation of growth, only DNA is stable and RNA undergoes appreciable degradation (e.g., see Mandelstam, 1960). With Aerobacter aerogenes the RNA of cells harvested from a glucose-tryptone medium is much more stable than that of cells from defined or tryptic meat broth media (Strange, Dark \& Ness, 1961). The importance of $\mathrm{Mg}^{2+}$ as a stabilizer of ribonucleoprotein has been established (Bowen, Dagley \& Sykes, 1959), and Wade (1961) has demonstrated two routes of RNA breakdown, one of which is dependent on $\mathrm{Mg}^{2+}$. We have not been concerned with the fate of the nucleosides produced and released in RNA degradation, but net deamination clearly does not occur during the period of glycogen utilization.

A comparison of our observations with $E$. coli with the extensive findings of the Porton workers (Strange et al. 1961; Strange, Wade \& Ness, 1963; Postgate \& Hunter, 1962, 1963) on the starvation and survival of $A$. aerogenes is pertinent. They showed that washed suspensions of cells harvested from carbon-limiting mannitol-ammonium salts medium contained only small amounts of carbohydrate $(5 \cdot 8 \%)$ and degraded their protein and RNA with little change of carbohydrate content, whereas cells from a complex tryptone-glucose medium had a high carbohydrate content (15-20\%) and glycogen was depleted during the initial $25 \mathrm{hr}$. of starvation with a small change in protein and no change in RNA content. The rate of loss of glycogen at $37^{\circ}$ was much less than we have observed with $E$. coli; indeed, one of the striking features of our findings has been the rapidity with which cellular glycogen is metabolized by starving cells.

Strange et al. (1961) concluded that the presence of glycogen in the cell favours survival of $A$. aerogenes, and showed that when it is not available protein and RNA may yield readily metabolized sources of carbon as amino acids and ribose, the nitrogen appearing as ammonia and free bases, although ammonia had not been detected by Gronlund \& Campbell (1961). On the other hand, the addition of exogenous glucose to the suspensions greatly accelerated death. In contrast with $E$. coli the endogenous amino acid concentration of $A$. aerogenes decreased during starvation (Strange et al. 1963) ; our measurements, however, were made over much shorter periods (see, e.g., Fig. 3). The degradation of ribosomal RNA did not increase the RNA in the suspending fluid, but degradation products, mainly deaminated bases, were released.

Comparison with the observations of Strange et al. (1961) suggests that $A$. aerogenes harvested from a defined medium survives better than does $E$. coli under aerobic conditions at $37^{\circ}$. After $12 \mathrm{hr}$. starvation without significant loss of viability, $E$. coli dies more rapidly under anaerobic than aerobic conditions, probably because of accumulation of the products of glycogen fermentation.

We are indebted to the Royal Society for a Grant-in-Aid. Part of this work was done while we were members of the Biochemistry Department of the University of Glasgow 
and we are grateful for facilities provided there. The technical assistance of Mrs Irene Thomson, Mr J. Hastings and Miss Christine Ezard is gratefully acknowledged.

\section{REFERENCES}

Bolleter, W. T., Bushman, C. J. \& Tidwell, P. W. (1961). Analyt. Chem. 33, 592.

Bowen, T. J., Dagley, S. \& Sykes, J. (1959). Biochem. J. $72,419$.

Campbell, J. J. R., Gronlund, A. F. \& Duncan, M. G. (1963). Ann. N.Y. Acad. Sci. 102, 669.

Cowgill, R. W. \& Pardee, A. B. (1957). Experiments in Biochemical Research Techniques, p. 158. New York: John Wiley and Sons Inc.

Dagley, S. \& Dawes, E. A. (1949). Biochem. J. 45, 331.

Dagley, S., Dawes, E. A. \& Morrison, G. A. (1950). J. gen. Microbiol. 4, 437.

Dagley, S. \& Johnson, A. R. (1953). Biochim. biophys. Acta, $11,158$.

Dawes, E. A. \& Holms, W. H. (1958a). Biochim. biophys. Acta, 30, 278.

Dawes, E. A. \& Holms, W. H. (1958b). Biochim. biophys. Acta, 29, 82.

Dawes, E. A. \& Ribbons, D. W. (1962a). Annu. Rev. Microbiol. 16, 241.

Dawes, E. A. \& Ribbons, D. W. (1962b). Biochem. J. 82, 49 P.

Dawes, E. A. \& Ribbons, D. W. (1962c). Biochem. J. 84, $97 \mathrm{P}$.

Dawes, E. A. \& Ribbons, D. W. (1964). Bact. Rev. 28, 126. Duncan, M. G. \& Campbell, J. J. R. (1962). J. Bact. 84, 784.

Fleck, A. \& Munro, H. N. (1962). Biochim. biophys. Acta, 55, 571.

Gronlund, A. F. \& Campbell, J. J. R. (1961). J. Bact. 81, 721.

Gronlund, A. F. \& Campbell, J. J. R. (1963). J. Bact. 86, 58.

Holme, T. \& Palmstierna, H. (1956a). Acta chem. scand. $10,578$.
Holme, T. \& Palmstierna, H. (1956b). Acta chem. scand. 10, 1557.

Lowry, O. H., Rosebrough, N. J., Farr, A. L. \& Randall, R. J. (1951). J. biol. Chem. 193, 265.

McGrew, S. B. \& Mallette, M. F. (1962). J. Bact. 83, 844.

Mandelstam, J. (1958). Biochem. J. 69, 110.

Mandelstam, J. (1960). Bact. Rev. 24, 289.

Mandelstam, J. \& Halvorson, H. (1960). Biochim. biophys. Acta, 40, 43.

Marr, A. G., Nilson, E. H. \& Clark, D. J. (1963). Ann. N.Y. Acad. Sci. 102, 536.

Mejbaum, W. (1939). Hoppe-Seyl. Z. 258, 117.

Neish, A. C. (1952). Rep. nat. Res. Coun. Can. no. 46-8-3: Analytical Methods for Bacterial Fermentations (2nd revision).

Neish, A. C. (1957). In Methods in Enzymology, vol. 3, p. 255. Ed. by Colowick, S. P. \& Kaplan, N. O. New York: Academic Press Inc.

Nelson, N. (1944). J. biol. Chem. 153, 375.

Palmstierna, H. (1956). Acta chem. scand. 10, 567.

Paul, J. (1958). Analyst, 83, 37.

Postgate, J. R. \& Hunter, J. R. (1962). J. gen. Microbiol. 29, 233.

Postgate, J. R. \& Hunter, J. R. (1963). J. appl. Bact. 26, 295.

Ribbons, D. W. \& Dawes, E. A. (1963). Ann. N.Y. Acad. Sci. 102, 564.

Roberts, R. B., Abelson, P. H., Cowie, D. B., Bolton, E. T. \& Britten, R. J. (1957). Publ. Carneg. Instn no. 607: Studies of Biosynthesis in Escherichia coli.

Sakami, W. (1955). Handbook of Isotope Tracer Methods, p. 1. Cleveland: Western Reserve University.

Stickland, L. H. (1951). J. gen. Microbiol. 5, 698.

Strange, R. E., Dark, F. A. \& Ness, A. G. (1961). J. gen. Microbiol. 25, 61.

Strange, R. E., Wade, H. E. \& Ness, A. G. (1963). Biochem. J. 86, 197.

Trevelyan, W. D. \& Harrison, J. S. (1952). Biochem. J. 50, 298.

Wade, H. E. (1961). Biochem. J. 78, 457.

Yemm, E. M. \& Cocking, E. C. (1955). Analyst. 80, 209. 